Article

\title{
Human Impact on Vegetation Dynamics around Lhasa, Southern Tibetan Plateau, China
}

\author{
Haidong $\mathrm{Li}^{1}$, Yingkui $\mathrm{Li}^{2}$, Yuanyun Gao ${ }^{1}$, Changxin Zou ${ }^{1}$, Shouguang Yan ${ }^{1}$ and Jixi Gao ${ }^{1, *}$ \\ 1 Nanjing Institute of Environmental Sciences, Ministry of Environmental Protection, Nanjing 210042, China; \\ Lihd2020@163.com (H.L.); gaoyy1991@163.com (Y.G.); Zcx@nies.org (C.Z.); Ysg@nies.org (S.Y.) \\ 2 Department of Geography, University of Tennessee, Knoxville, TN 37996, USA; yli32@utk.edu \\ * Correspondence: Gjx@nies.org; Tel.: +86-25-8528-7278
}

Academic Editor: Tan Yigitcanlar

Received: 13 September 2016; Accepted: 3 November 2016; Published: 8 November 2016

\begin{abstract}
Human impact plays an increasing role on vegetation change even on the Tibetan Plateau, an area that is commonly regarded as an ideal place to study climate change. We evaluate the nature and extent of human impact on vegetation dynamics by the comparison of two areas: the relative highly populated Lhasa area and a nearby less populated Lhari County. Our results indicate that human impact has mainly decreased vegetation greenness within $20 \mathrm{~km}$ of the urban area and major constructions during 1999-2013. However, the impact of human activities in a relatively large area is still minor and does not reverse the major trends of vegetation dynamics caused by the warming temperature in recent decades. It seems that the impact of anthropogenic factors on the normalized difference vegetation index (NDVI) trend is more apparent in the Lhasa area than in Lhari County. The major anthropogenic driving factor for vegetation browning in the Lhasa area is livestock number, while the factors, including the number of rural laborers and artificial forest areas, are positively correlated with the annual NDVI increase. The similar relationship between the annual NDVI and driving factors appeared in Lhari County, except for artificial forest areas. The warming temperature and the change in precipitation played dominant roles on vegetation greening in Lhari County than that in the Lhasa area.
\end{abstract}

Keywords: vegetation dynamics; human impact; global change; adaptation strategy; Tibetan Plateau

\section{Introduction}

The status of vegetation is commonly used to assess the productivity of natural or agricultural lands $[1,2]$. In recent decades, an increasing trend in vegetation greenness has been reported at global and various regional scales [3,4]. In contrast, a browning trend, which is an indication of land degradation, has been only reported in some areas [5,6]. Vegetation change is affected by both climate change and the increasing human activities. Climate factors, such as temperature and precipitation, affect environmental conditions for vegetation growth $[7,8]$. Anthropogenic factors, such as overgrazing, urbanization and road construction [9], influence vegetation change and regional ecological services.

The Tibetan (Qinghai-Xizang) Plateau, known as the "roof of the world", is sparsely populated, with an average population density of 2.6 people $/ \mathrm{km}^{2}$ in $2013[10,11]$. It is a sensitive region to climate change [12,13], and has been regarded as an ideal place to study the impact of climate change on environment [14-17]. Since 1999, "the Western Regions Development Strategy" has been implemented by the Chinese government. Major cities in this region have been experiencing rapid urbanization and transportation infrastructure improvement [18]. At the same time, a series of ecological protection and restoration projects have been implemented to prevent and restore degraded land. Vegetation greening has been promoted in certain areas of the Tibetan Plateau $[11,19,20]$, whereas the progressive 
urbanization and road constructions have also caused land degradation and desertification in some areas [21-23]. However, the nature and extent of human impact on vegetation dynamics on the Tibetan Plateau has not been fully examined, especially within and around major cities and highways/railways. Monitoring and assessing the dynamic changes in vegetation at regional scale could help quantify the roles of climatic and anthropogenic factors on terrestrial ecosystems [3,24]. Thus, it is of critical importance to fully understand the pattern of annual and seasonal vegetation changes in relative highly populated area and less populated area of the Tibetan Plateau, and how it responds to human activities.

In this paper, we use normalized difference vegetation index (NDVI) as an indicator of vegetation greenness to investigate the pattern of vegetation dynamics in Lhasa area and examine the potential impact of human activities on NDVI trend from 1999 to 2013 based on the comparison with a primarily climate-induced area of Lhari County. The purpose of this paper is to investigate the vegetation dynamics in a human-affected region on the Tibetan Plateau, and examine the roles of climatic and anthropogenic factors played on vegetation change. The findings from this work will provide useful information for decision-makers in ecological protection and sustainable development on the Tibetan Plateau.

\section{Methods}

\subsection{Study Area}

Lhasa, the capital and largest city of Tibet, is located in the midstream of the Yarlung Zangbo River basin on the southern Tibetan Plateau, China (Figure 1). The Lhasa area covers $26,784 \mathrm{~km}^{2}$, extending from $89^{\circ} 45^{\prime} \mathrm{E}$ to $92^{\circ} 37^{\prime} \mathrm{E}$, and from $29^{\circ} 14^{\prime} \mathrm{N}$ to $30^{\circ} 49^{\prime} \mathrm{N}$, and includes seven counties, including five agriculture counties of Maizhokunggar, Dagzê, Doilungdêqên, Qüxü and Nyêmo, two grazing counties of Damxung and Lhünzhub, and the Lhasa suburban district. The range of elevations in the Lhasa area is from $3581 \mathrm{~m}$ to $>7000 \mathrm{~m}$ with an averaged elevation of $4818 \mathrm{~m}$ above sea level. This area has the largest population in Tibet, with a density of 19.0 people $/ \mathrm{km}^{2}$. Two national highways, 109 and 318, pass through this area. The cultivated areas are around 34,899 ha in 2013.

To investigate the human impact on vegetation change of the Lhasa area, we selected Lhari County, a typical grazing county, as a reference area to derive natural vegetation change. Lhari County is located in the upstream of Lhasa River and Parlung Tsangpo River with an area of $13,213 \mathrm{~km}^{2}$. The range of elevation is from $3052 \mathrm{~m}$ to $6599 \mathrm{~m}$ with an averaged elevation of $5047 \mathrm{~m}$ above sea level. The population density of Lhari County is around 2.4 people $/ \mathrm{km}^{2}$. No national highway passes through this county. The cultivated areas are 312 ha in 2013.

\subsection{Data Collection and Analysis}

\subsubsection{Datasets}

We used the NDVI dataset derived from the vegetation instrument of the Système Pour l'Observation de la Terre (SPOT-VGT) 4 and 5 satellites to explore spatial pattern of annual and seasonal NDVI changes during 1999-2013. The spatial resolution of the SPOT-VGT NDVI raster is $1 \mathrm{~km}$, and the temporal resolution is about 10 days [25]. To ensure SPOT-VGT NDVI data quality, the maximum value composite (MVC) for each 10-day interval was derived to minimize the non-vegetation effects on SPOT satellite images [26], and the atmospheric contaminations, including water vapor, ozone and aerosols, were removed through the simplified method for atmospheric corrections (SMAC) [27].

We divided a full year into 4 seasons: spring (April to May), summer (June to August), autumn (September to October), and winter (November to March). We calculated the seasonal NDVIs and annual NDVI rasters through averaging the NDVI series in each season or each year during 1999-2013. We downloaded glacier data from the recent released Second Glacier Inventory of China [28]. The area covered by glaciers was removed to reduce the noise in the derived NDVI for vegetation greening and browning analysis. Based on the NDVI value of each cell of the Lhasa area or Lhari County, we 
also derived spatially averaged seasonal NDVI values for each season or each year to analyze the inter-annual change in NDVI.

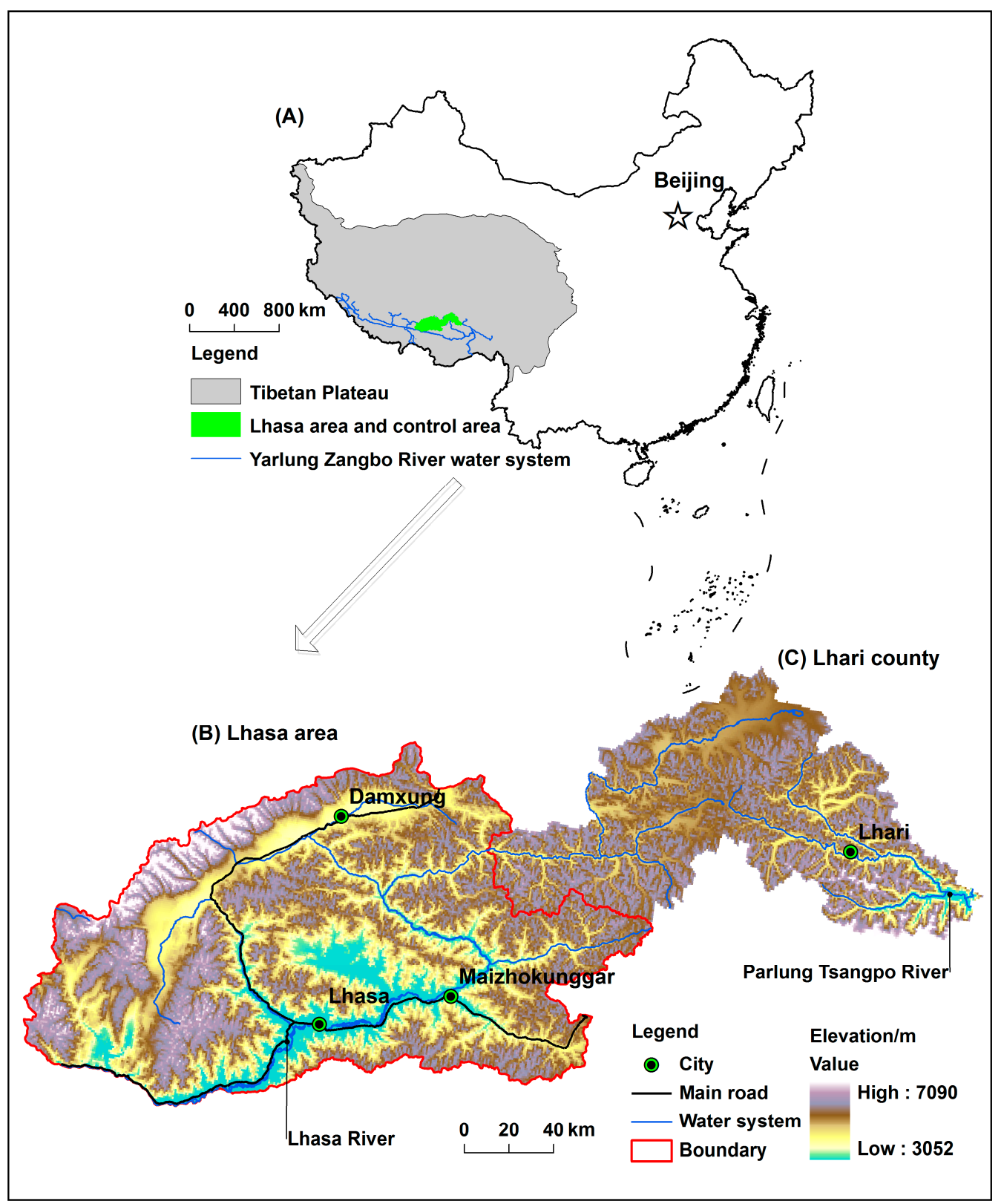

Figure 1. The location of Lhasa area in southern Tibetan Plateau, China (A); topographic characteristics of Lhasa area (B); and Control area (Lhari County) (C).

We collected the monthly temperature and precipitation records from Lhasa and Lhari meteorological stations in 1999-2013 from the China Meteorological Data Sharing Service Network [11]. The seasonally averaged values and changing rates of annual mean temperature, annual precipitation, seasonal mean temperature and seasonal precipitation were calculated to investigate the relationship between vegetation greening and browning trend and climate changes.

The land use data in 2000 and major roads data were collected to examine the impact of urbanization and road construction on vegetation greening or browning. The socio-economic statistical data in Lhasa area and Lhari County, including number of rural laborers, artificial forest areas (accumulatively calculated from current new forest area since 1999 in Lhasa area), cultivated areas, 
livestock numbers from 1999 to 2013, were collected to refine the roles of climate change and human activities played on vegetation greening and browning.

Figure 2 illustrates the histograms of the annual NDVIs, climatic factors (annual mean temperature, annual precipitation), and anthropogenic factors (number of rural laborers, artificial forest areas, cultivated areas, livestock numbers). Most of these variables are likely normally distributed according to the non-parametric Kolmogorov-Smirnov test, except for livestock numbers in the Lhasa area, number of rural laborers and cultivated areas in the Lhari County. We standardized each variable to eliminate the possible impact caused by different dimensions. The method of standardization is based on $z=(x-\mu) / \sigma$ where $z$ is the standardized data, $x$ is the original data, $\mu$ is the arithmetic mean of original data, and $\sigma$ is the standard deviation.
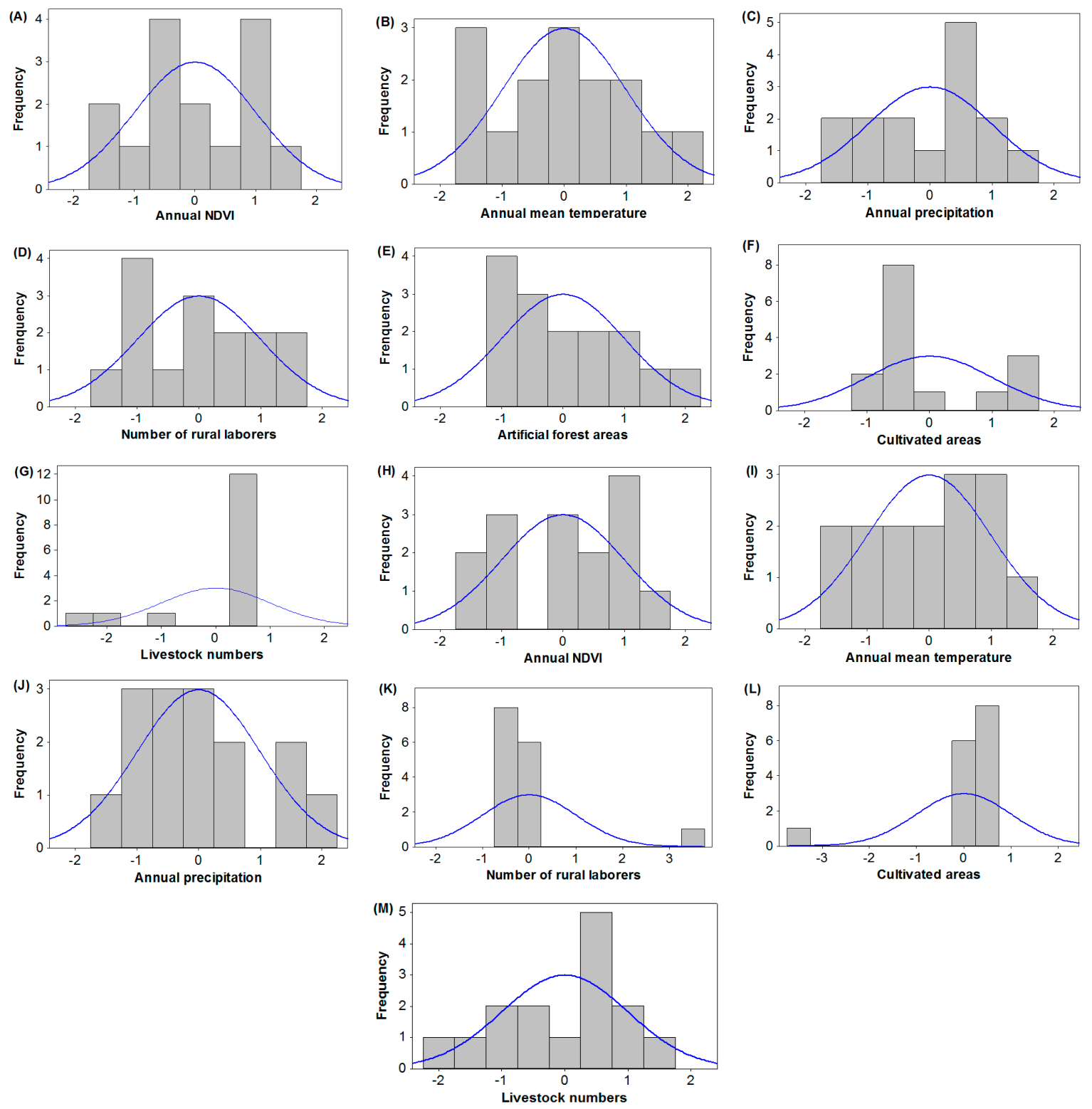

Figure 2. Histograms for annual NDVIs, climatic factors and anthropogenic factors in: the Lhasa area (A-G); and the Lhari County $(\mathbf{H}-\mathbf{M})$. All data are normalized. 


\subsubsection{Temporal Trend and Correlation Analyses}

We applied a linear regression model to detecting the changing rate in NDVI trend (greening rate $>0$, browning rate $<0$ ), temperature and precipitation changes during 1999-2013. The regression model is as follows:

$$
y=a t+b
$$

where, $y$ is the NDVI, temperature, or precipitation, respectively; $t$ is the time (year) from 1999 to 2013; $a$ is the slope, indicating the changing rate; and $b$ is the intercept of the regression. The $p$-value is calculated to evaluate the statistical significance of the regression, with $p$-values of 0.05 and 0.01 representing the statistical significance at the confidence level of $95 \%$ and $99 \%$ respectively.

Pearson's correlation analysis was conducted to investigate the relationship between seasonal NDVIs and climatic factors of Lhasa area and Lhari County during 1999-2013. This analysis calculates a correlation coefficient $(\mathrm{r})$ to measure the strength of the correlation and a $p$-value to represent the statistical significance of the correlation between each NDVI and climate factor.

\subsubsection{Spatial Analysis}

To analyze the spatial pattern of NDVI changes affected by human impact, we extracted the urban area and major roads in Lhasa area from the land use data in 2000 and the shape files of national highways 109 and 318, respectively. Then, we generated a distance raster to the urban area and major roads to examine the pattern of annual NDVI changing trend around urban area and road constructions. This distance raster represents the shortest distance from each pixel of the whole study area to the urban land and major roads, comparable to the multiple buffering analysis when conducting a vector based analysis. An advantage of the raster-based distance calculation is that it provides detailed distance values for each pixel instead of a range of distances from the multiple buffering analysis. Based on this distance raster, we investigated the rate of vegetation greening or browning with the distance from urban area or road within the range of $45 \mathrm{~km}$, respectively.

\subsubsection{Grey Relational Analysis}

To quantify the contributions of the climatic and anthropogenic factors to vegetation change, we first made a comparison between annual NDVI trend and different driving factors during 1999-2013 to assess the relationship. Then, we calculated the relational degree using grey relational analysis to determine the order of relational degree between annual NDVI change and various driving factors. The equation is as follows:

$$
R_{o m}(t)=\frac{\Delta_{\min }+\rho \Delta_{\max }}{\Delta_{o m}(t)+\rho \Delta_{\max }}
$$

where $R_{o m}(t)$ is the relational coefficient between two sequences at $t$ time; $\Delta_{\min }$ and $\Delta_{\max }$ represents the minimal and maximal difference of the sequences, respectively; $\Delta_{o m}(t)$ represents absolute value of the difference between two sequences; and $\rho \in(0,1]$ is the coefficient to distinguish the degree of proximity, usually this value is 0.5 . We calculate average relational coefficient for a time period $T$, as following:

$$
R_{o m}=\frac{1}{T} \sum_{t=1}^{T} R_{o m}(t)
$$

\section{Results}

\subsection{Temporal Pattern of Annual and Seasonal NDVI Changes}

The annual NDVI values in the Lhasa area and Lhari County both showed a significantly increasing trend during 1999-2013, with a rate of 0.0016 year $^{-1}$ and 0.0024 year $^{-1}$ at the $99 \%$ confidence level $(p<0.01)$, respectively (Figure 3). The annual NDVI in Lhari County has increased by $9.32 \%$, with more apparent increase than that of in the Lhasa area (7.61\%). For the Lhasa area, the highest 
annual NDVI value was 0.215 in 2012, and the lowest was 0.181 in 2008. The seasonal NDVI values in the Lhasa area all exhibited an overall increasing trend during 1999-2013, with the rates ranging from 0.0012 year $^{-1}$ to 0.0024 year $^{-1}$ (Figure 4A-D). The seasonal NDVI values in the Lhari County showed similarly fluctuating but with increasing trends in comparison with that in the Lhasa area during 1999-2013 (Figure 4E-H). The changing rates range from 0.0008 year $^{-1}$ to 0.0031 year $^{-1}$, generally higher than that of in the Lhasa area, except for spring NDVI $\left(0.0008\right.$ year $\left.^{-1}\right)$. Both summer and winter NDVI increased significantly at the 95\% confidence level $(p<0.05)$, similar with that in the Lhasa area.

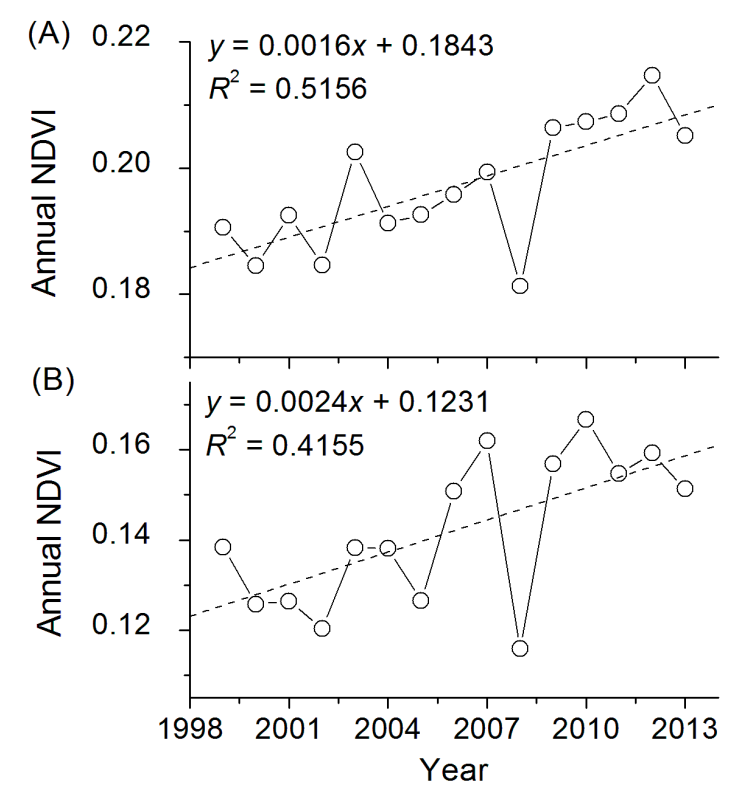

Figure 3. Changes of annual NDVI of: Lhasa area (A); and Lhari County (B) from 1999 to 2013.

The seasonal mean temperatures in the Lhasa area and the Lhari County both showed generally increasing trend from 1999 to 2013 . For the Lhasa area, the highest changing rate occurred in summer $\left(0.136{ }^{\circ} \mathrm{C} /\right.$ year $)$, followed by spring $\left(0.077^{\circ} \mathrm{C} /\right.$ year $)$, autumn $\left(0.068^{\circ} \mathrm{C} /\right.$ year $)$, and winter $\left(0.029{ }^{\circ} \mathrm{C} /\right.$ year $)$. However, only the increasing trend in summer temperature reached the $95 \%$ confidence level $(p<0.01)$, while none reached statistical significance at the $95 \%$ confidence level in the Lhari County.

The seasonal precipitations in the Lhasa area exhibited an overall decreasing trend, but none reached statistical significance at the 95\% confidence level, except for winter precipitation $(p<0.05)$, with a changing rate of $-0.25 \mathrm{~mm} /$ year. The highest decrease in the rate of precipitation was found in summer $(-3.73 \mathrm{~mm} /$ year), followed by autumn $(-2.85 \mathrm{~mm} /$ year $)$ and spring $(-2.20 \mathrm{~mm} /$ year $)$. The seasonal precipitations in the Lhari County also exhibited an overall decreasing trend, except for winter. The highest rate of decrease occurred in summer $(-4.17 \mathrm{~mm} /$ year), followed by autumn $(-3.31 \mathrm{~mm} /$ year) and spring $(-3.20 \mathrm{~mm} /$ year$)$, while the changing rate in winter was $0.342 \mathrm{~mm} /$ year. Spring and autumn precipitation both reached statistical significance at the $95 \%$ confidence level $(p<0.05)$. 

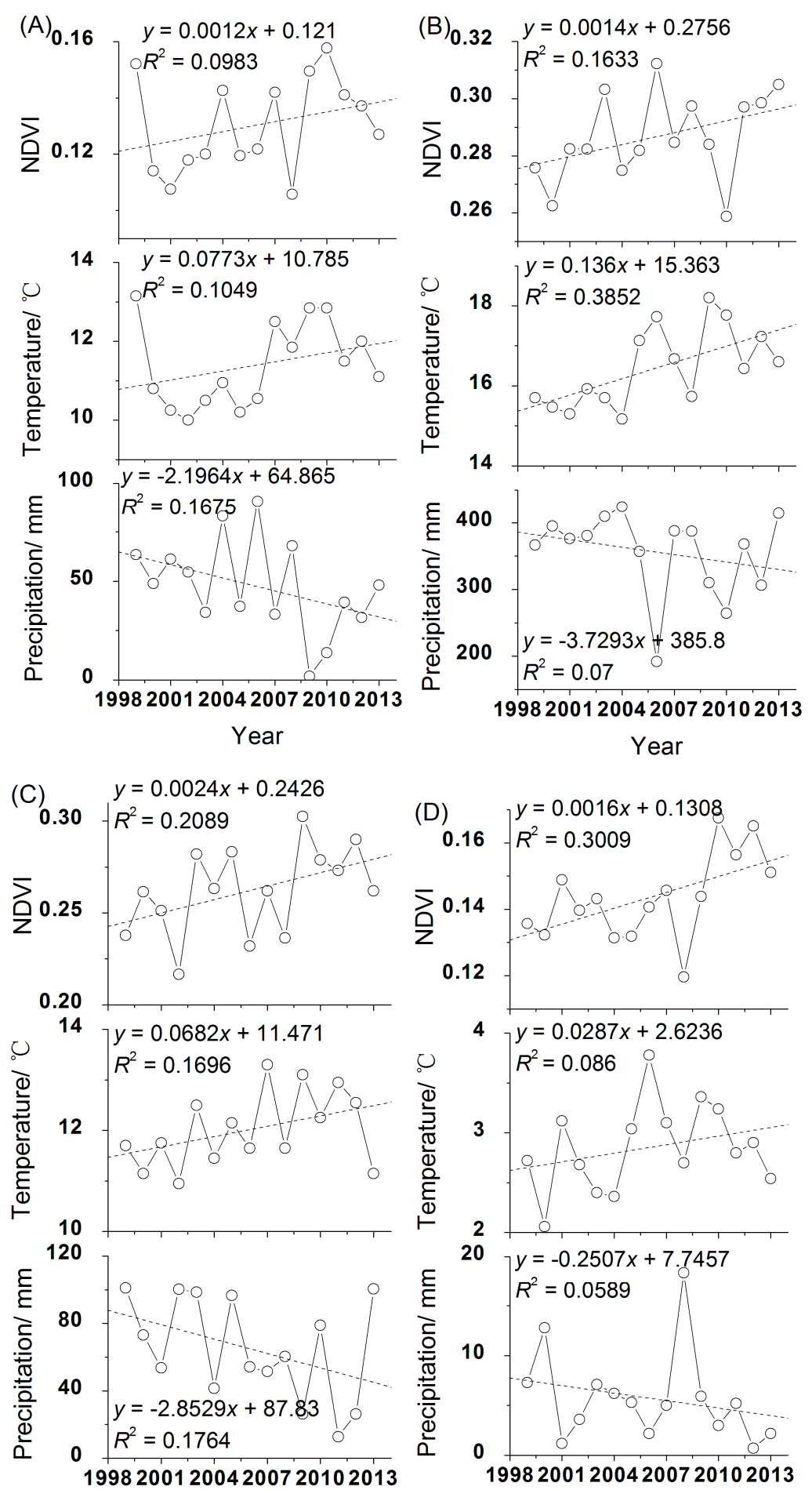

Year

Year

Figure 4. Cont. 

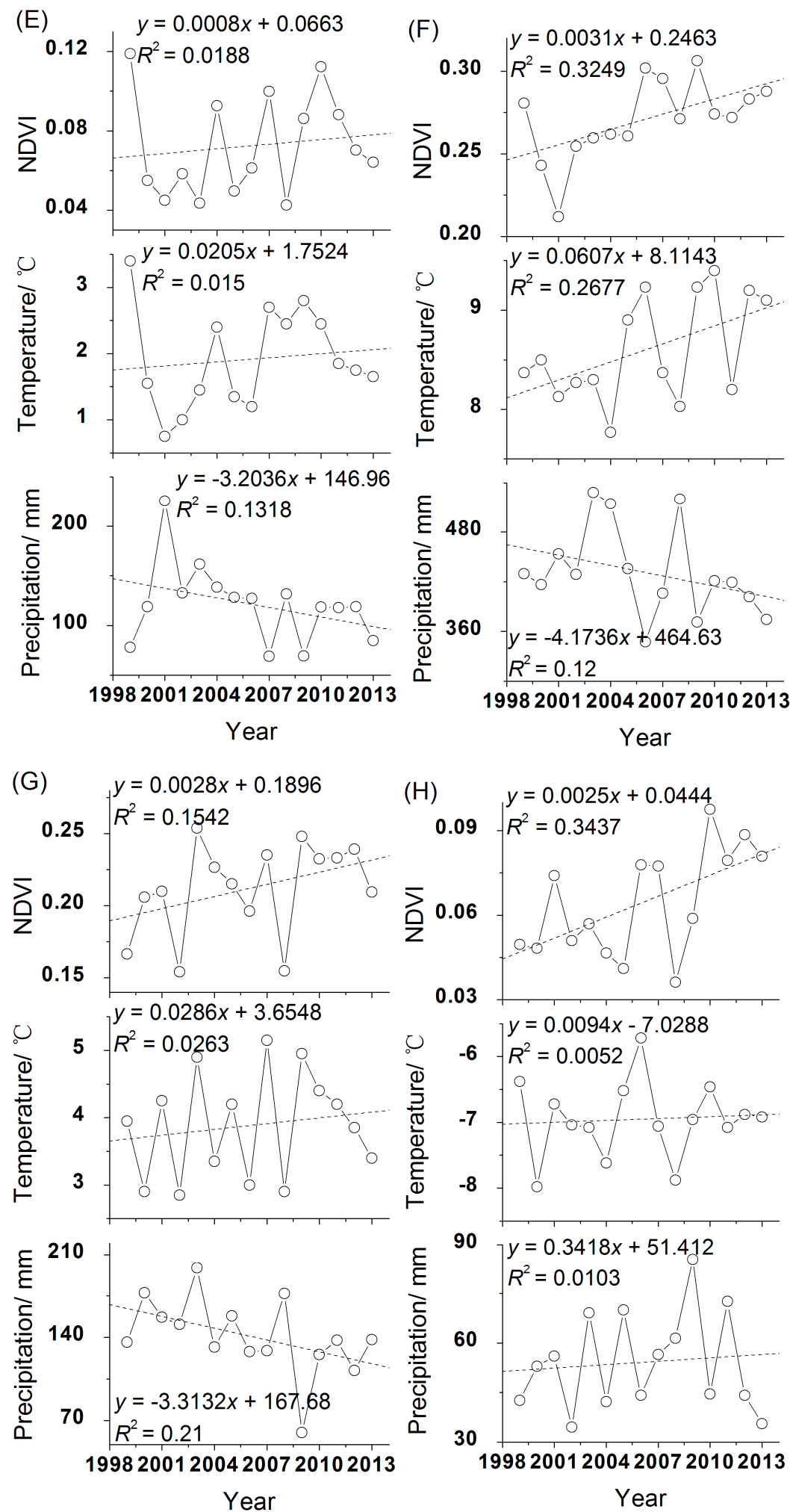

Figure 4. Inter-annual changes of seasonal NDVIs, mean temperatures, and precipitations of: Lhasa area (A-D); and Lhari County; (E-H) from 1999 to 2013; (A,E) spring NDVI trend (April-May); (B,F) summer NDVI trend (June-August); (C,G) autumn NDVI trend (September-October); (D,H) and winter NDVI trend (November-March). 
Correlation between NDVI and Climatic Factors

The increase in the seasonal NDVIs were positively correlated with rising temperatures, and negatively related with decreasing precipitations in both the Lhasa area and Lhari County (Table 1). Specifically, spring and autumn NDVIs in the Lhasa area showed significantly positive correlation with temperature changes $(r=0.765$ and $0.665 ; p<0.01)$, and winter NDVI exhibited a significantly negative relationship with precipitation $(r=-0.727 ; p<0.01)$. However, unlike the summer NDVI in the Lhasa area, which exhibits no significant correlation with climatic factors, the summer NDVI in the Lhari County was positively correlated with spring and summer rising temperatures $(r=0.545$ and 0.537; $p<0.05)$. It appears that the changes in seasonal NDVIs were more affected by climate change in the Lhari County than in the Lhasa area.

Table 1. Pearson correlation matrix between seasonal NDVIs and climatic factors of Lhasa area and Lhari County during 1999-2013.

\begin{tabular}{cccccccccc}
\hline \multirow{2}{*}{ Regions } & \multirow{2}{*}{ NDVI } & \multicolumn{3}{c}{ Seasonal Mean Temperatures } & \multicolumn{3}{c}{ Seasonal Precipitations } \\
\cline { 3 - 10 } & & Spring & Summer & Autumn & Winter & Spring & Summer & Autumn & Winter \\
\hline \multirow{2}{*}{ Lhasa } & Spring & $0.765^{* *}$ & 0.440 & 0.485 & 0.221 & -0.431 & -0.252 & -0.249 & -0.321 \\
Area & Summer & -0.253 & 0.158 & 0.120 & 0.227 & 0.246 & -0.133 & -0.144 & -0.148 \\
& Autumn & 0.293 & 0.449 & $0.665^{* *}$ & 0.045 & $-0.756^{* *}$ & -0.045 & -0.354 & -0.182 \\
& Winter & 0.274 & 0.476 & 0.413 & 0.314 & $-0.529^{*}$ & -0.372 & -0.265 & $-0.727^{* *}$ \\
\hline \multirow{2}{*}{ Lhari } & Spring & $0.767^{* *}$ & 0.140 & 0.341 & 0.230 & $-0.595^{*}$ & -0.257 & $-0.577^{*}$ & -0.159 \\
County & Summer & $0.545^{*}$ & $0.537^{*}$ & 0.180 & 0.319 & $-0.821^{* *}$ & $-0.518^{*}$ & $-0.633^{*}$ & 0.063 \\
& Autumn & 0.037 & 0.299 & $0.716^{* *}$ & 0.042 & -0.045 & -0.086 & -0.309 & 0.454 \\
& Winter & -0.090 & $0.549^{*}$ & 0.318 & 0.469 & -0.061 & $-0.532^{*}$ & -0.392 & -0.217 \\
\hline
\end{tabular}

** presents $p<0.01 ;{ }^{*}$ presents $p<0.05$.

\subsection{Spatial Pattern of the NDVI Change}

\subsubsection{Seasonal Vegetation Greening and Browning}

Although the seasonal NDVI values exhibited an overall increasing trend in the Lhasa area and Lhari County during 1999-2013, the spatial patterns of seasonal NDVI trends varied markedly (Figure 5). The largest spatially averaged value of changing rate in the Lhasa area appeared in autumn $\left(0.0025\right.$ year $\left.^{-1}\right)$, followed by winter $\left(0.0016\right.$ year $\left.^{-1}\right)$, summer $\left(0.0014\right.$ year $\left.^{-1}\right)$, and spring $\left(0.0013\right.$ year $\left.^{-1}\right)$, while in Lhari County, it followed the order of summer $\left(0.0029\right.$ year $\left.^{-1}\right)$, autumn $\left(0.0026\right.$ year $\left.^{-1}\right)$, winter $\left(0.0025\right.$ year $\left.^{-1}\right)$, and spring $\left(0.0011\right.$ year $\left.^{-1}\right)$.

The area of vegetation greening (changing rate $>0$ ) in the Lhasa area followed the order of winter $(92.6 \%)$, autumn $(88.6 \%)$, spring $(87.2 \%)$ and summer $(72.9 \%)$ (Figure $4 \mathrm{~A}-\mathrm{D})$. In contrast, the largest area of browning (changing rate $<0$ ) appeared in summer $(27.1 \%)$. The browning regions in summer NDVI were primarily distributed in the wide valleys where major road passes and cities locate (Figure 5), characterizing in the form of fragmented patches. In comparison, the largest area of vegetation greening in the Lhari County exhibited in winter (96.9\%), followed by summer $(93.2 \%)$, autumn (89.8\%) and spring (74.8\%) (Figure 5E,F). Spring NDVI had the largest area of browning $(25.2 \%)$, of which mainly distributed at higher elevations close to glacier or seasonal snow coverages. 


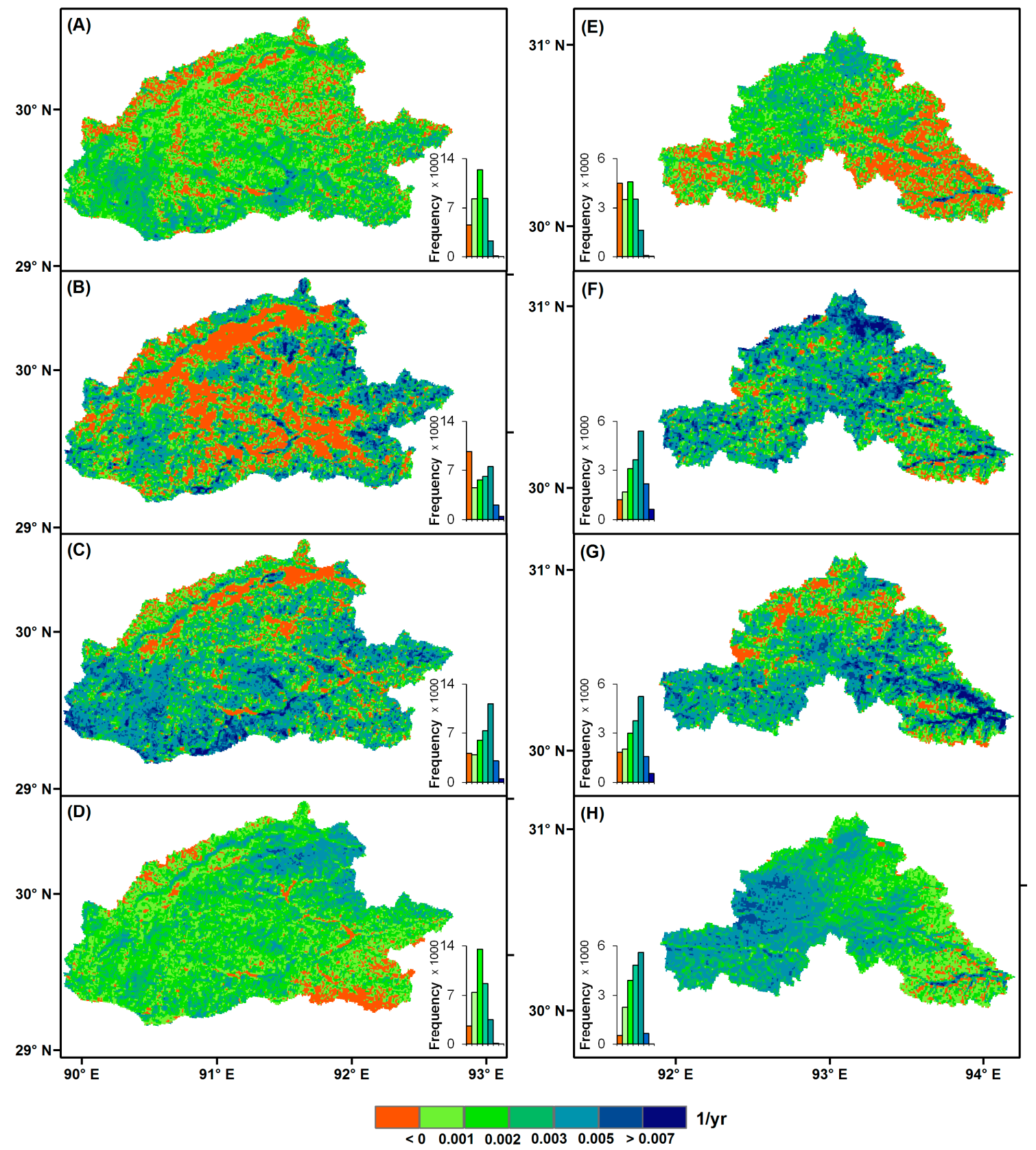

Figure 5. Spatial patterns of the changing rate in seasonal NDVIs of: Lhasa area (A-D); and Lhari County (E-H) during 1999-2013; (A,E) spring NDVI trend (April-May); (B,F) summer NDVI trend (June-August); (C,G) autumn NDVI trend (September-October); and $(\mathbf{D}, \mathbf{H})$ winter NDVI trend (November-March).

\subsubsection{Effects of Urbanization and Road Construction}

The changing rates of vegetation greening showed almost no changes as distance increases from urban area, while the decreasing browning trend exhibited within the distance of $45 \mathrm{~km}$ (Figure 6A,B). Among $2045 \mathrm{~km}^{2}$ within the range of $20 \mathrm{~km}$ around the urban area, the areas of vegetation greening and browning were $1869 \mathrm{~km}^{2}$ and $174 \mathrm{~km}^{2}$, respectively, during 1999-2013, accounting for $91.4 \%$ and $8.5 \%$ of the total area. These indicated that urbanization has resulted in vegetation browning, and the closer the distance to the urban area, the lower the greening rate exhibiting.

Similar to the greening rate around the urban area, the changing rate of vegetation greening exhibited almost no changes with the increase of distance from road within $45 \mathrm{~km}$, while the greening 
rate for vegetation browning gradually increased as distance increase, especially within the distance of $20 \mathrm{~km}$. Among 15,479 $\mathrm{km}^{2}$ within the distance of $20 \mathrm{~km}$ from the major roads in the Lhasa area, the areas of vegetation greening and browning accounted for $83.8 \%$ and $15.9 \%$ of the total area, respectively, from 1999 to 2013 (Figure 6C,D). The vegetation browning within $20 \mathrm{~km}$ from the major roads had greater proportion than that of around the urban area, indicating that road construction or maintenance may cause more significant vegetation browning than urbanization.

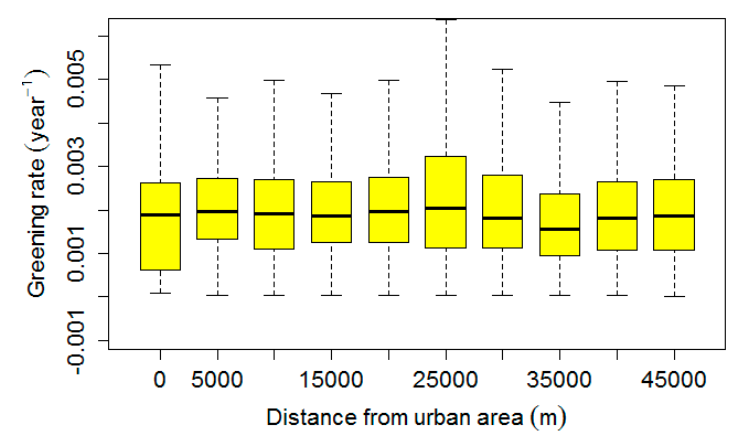

(A)

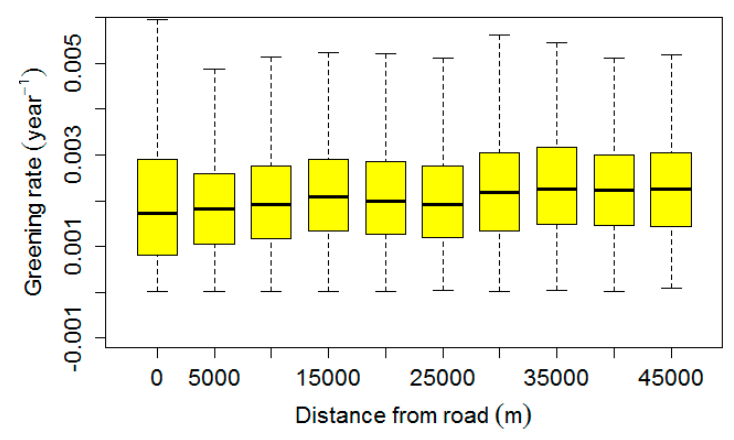

(C)

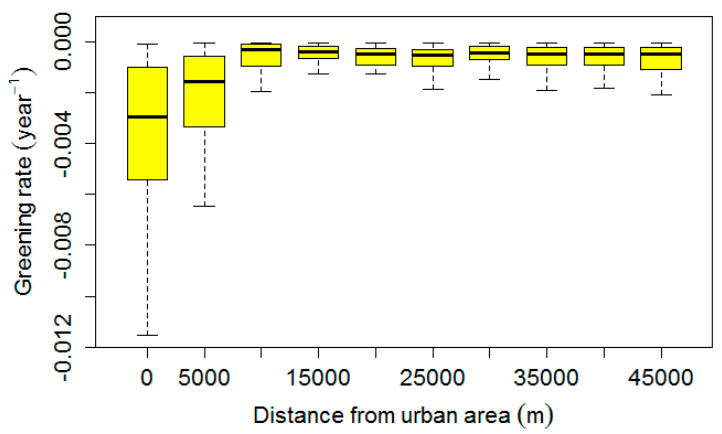

(B)

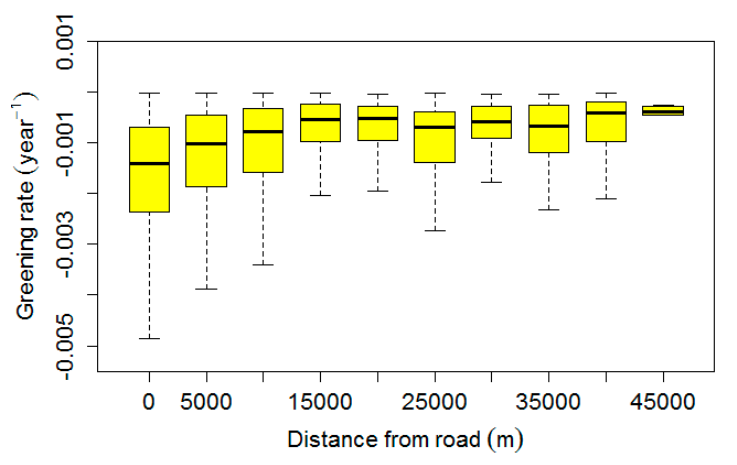

(D)

Figure 6. Pattern of vegetation greening (A); and browning (B) around the urban area. Pattern of vegetation greening (C); and browning (D) from the major roads during 1999-2013.

\subsection{Contributions of Anthropogenic Factors to NDVI Trend}

For the Lhasa area, the annual NDVI trend was positively related to the number of rural laborers ( $x 1)$, artificial forest areas $(x 2)$, and annual mean temperature $(x 5)(r=0.615,0.711$ and 0.711 , respectively; $p<0.05)$, while negatively correlated with livestock number $(x 4)$, and annual precipitation (x6) $(r=-0.566$ and -0.672 , respectively; $p<0.05)$ (Table 2). From 1999 to 2013 , the number of rural laborers $(x 1)$ and artificial forest areas $(x 2)$ have increased steadily by $31 \%$ and $70 \%$, respectively, both peaked in 2013 (at 158,920 persons and 97,699.2 ha, respectively) (Figure 7). Meanwhile, the cultivated areas (x3) and livestock number (x4) decreased rapidly from 1999 to 2013, especially in the periods of 1999-2005 and 2010-2013. The highest relational degree of 0.829 appeared in the association of annual NDVI with artificial forest areas $(x 2)$, followed by number of rural laborers $(x 1)(0.817)$, annual mean temperature $(x 5)(0.732)$, livestock number $(x 4)(0.618)$, cultivated areas $(x 3)(0.592)$, and annual precipitation ( $x 6$ ) (0.565).

The similar relationship between the annual NDVI and driving factors appeared in the Lhari County, except for artificial forest areas $(x 2)$. However, only the correlations between the annual NDVI and climatic factors reached the 95\% confidence level $(p<0.05)$. The highest relational degree of 0.780 occurred in the association of annual NDVI with annual mean temperature $(x 5)$ (Table 2), followed by number of rural laborers $(x 1)(0.701)$, cultivated areas $(x 3)(0.655)$, livestock number $(x 4)(0.609)$, and 
annual precipitation $(x 6)(0.542)$. In total, it seems that the number of rural laborers $(x 1)$ and artificial forest areas ( $x 2$ ) have promoted the annual NDVI increase during 1999-2013, while cultivated areas $(x 3)$ and livestock number $(x 4)$ constrained the increase of annual NDVI. The impact of anthropogenic factors on the NDVI trend is more apparent in the Lhasa area than in the Lhari County where climatic factors were the dominant factors for the increase of annual NDVI.

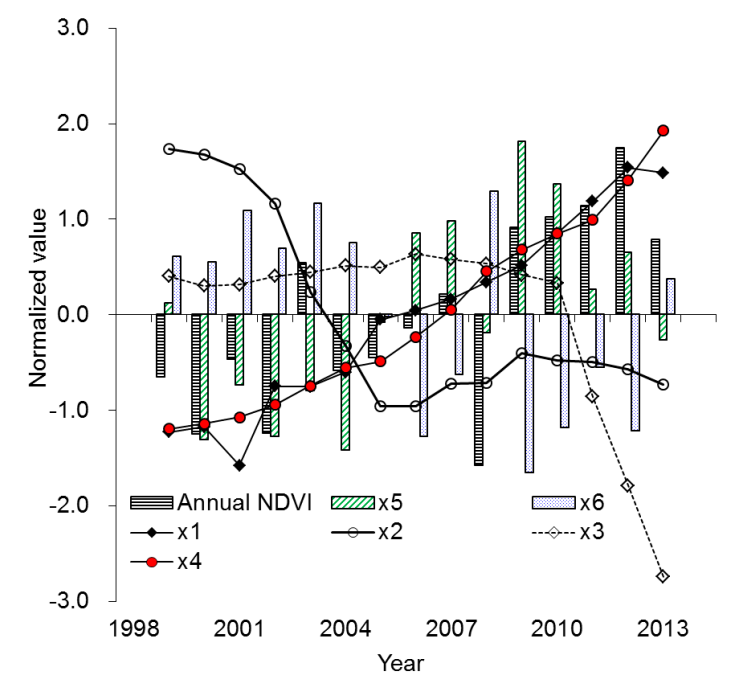

Figure 7. Comparison of annual NDVI relative to the proxies of climatic and anthropogenic factors in the Lhasa area during 1999-2013. All data are normalized. $x 1$ : number of rural laborers; $x 2$ : artificial forest areas; $x 3$ : cultivated areas; $x 4$ : livestock number; $x 5$ : annual mean temperature; and $x 6$ : annual precipitation.

Table 2. Pearson correlation coefficients and the grey relational degree between annual NDVI and anthropogenic and climatic factors, respectively in the Lhasa area and the Lhari County.

\begin{tabular}{|c|c|c|c|c|c|c|c|}
\hline \multicolumn{2}{|c|}{ Regions } & \multirow{2}{*}{$\begin{array}{c}\text { Number of } \\
\text { Rural Laborers } \\
(x 1)\end{array}$} & \multirow{2}{*}{$\begin{array}{c}\text { Artificial } \\
\text { Forest Areas } \\
(x 2)\end{array}$} & \multirow{2}{*}{$\begin{array}{l}\text { Cultivated } \\
\text { Areas }(x 3)\end{array}$} & \multirow{2}{*}{$\begin{array}{c}\text { Livestock } \\
\text { Number }(x 4)\end{array}$} & \multirow{2}{*}{$\begin{array}{c}\text { Annual Mean } \\
\text { Temperature } \\
(x 5)\end{array}$} & \multirow{2}{*}{$\begin{array}{c}\text { Annual } \\
\text { Precipitation } \\
(x 6)\end{array}$} \\
\hline Name & Elevation/m & & & & & & \\
\hline $\begin{array}{l}\text { Lhasa } \\
\text { area }\end{array}$ & 4818 & $0.711 * * / 0.817$ & $0.711^{* *} / 0.829$ & $-0.466 / 0.592$ & $-0.566 * / 0.618$ & $0.615 * / 0.732$ & $-0.672^{* *} / 0.565$ \\
\hline $\begin{array}{l}\text { Lhari } \\
\text { County }\end{array}$ & 5047 & $0.388 / 0.705$ & & $-0.053 / 0.662$ & $-0.186 / 0.614$ & $0.709 * / 0.780$ & $-0.650^{* *} / 0.547$ \\
\hline
\end{tabular}

** presents $p<0.01$, * presents $p<0.05$. Before and after the symbol "/" refer to correlation coefficient and grey relational degree, respectively, both of them are between annual NDVI and driving factors.

\section{Discussion}

Human management and practices could affect vegetation changes greatly, although it is difficult to quantify the cause-and-effect of climatic and anthropogenic factors to the variations in vegetation productivity $[29,30]$. Our study showed that the patterns of vegetation change, especially browning, were not fully associated with the changes in climate variables (Figures 3 and 4), especially in the Lhasa area where the largest area of browning appeared in summer (27.1\%). According to local governments' statistics, over $59 \%$ of local inhabitants in the Lhasa area live on grazing or farming activities in 2009 [31]. However, the decrease of cultivated areas has been limited to $<2 \%$ of the Lhasa's total area due to the positive role of ecological protection countermeasures (Figure 8). For example, the large investment in ecological compensation has mitigated the damage of grassland, by paying herders incentives to reduce their livestock numbers. In contrast, the transformation of arable land to grassland or urban area could reduce the NDVI value at the regional scale. Thus, human activities can be acted as a double-edged sword: it could lead to vegetation browning, but may also be a positive way to restore degraded land. Both vegetation greening and browning have been accelerated by 
anthropogenic activities in the Lhasa area, while in the Lhari County, the NDVI trend was mainly affected by the changes in climate variables.

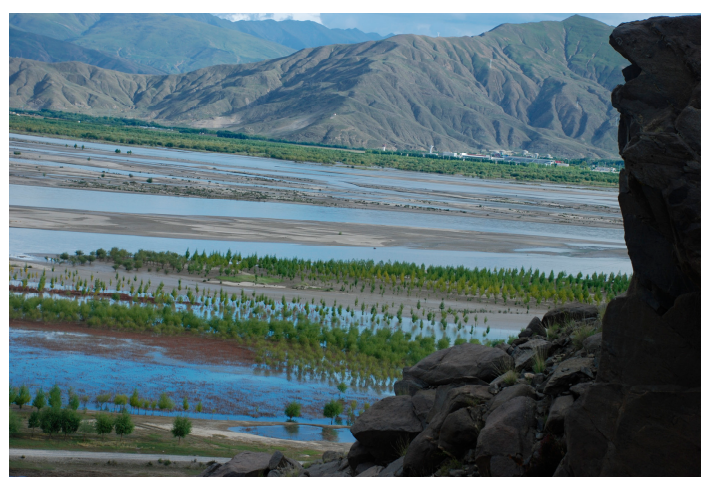

(A)

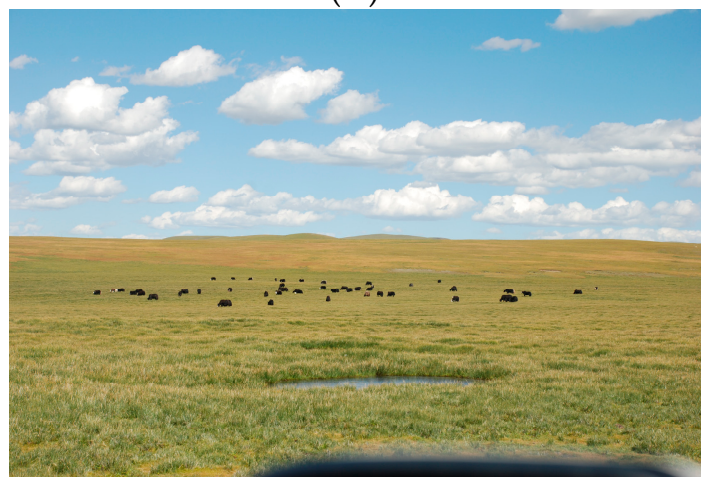

(C)

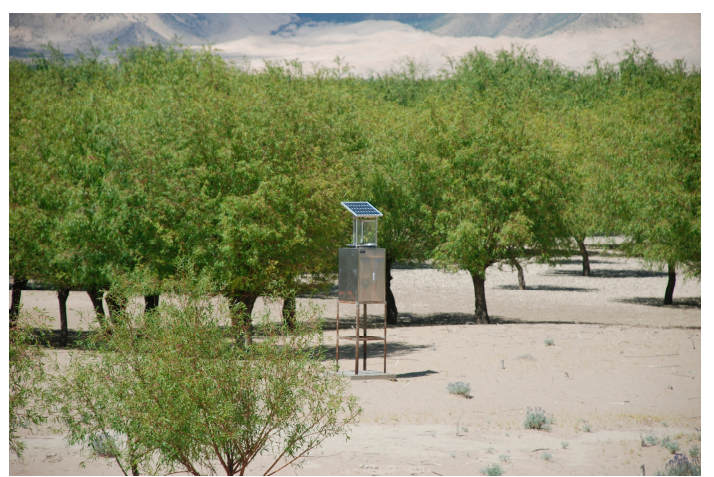

(B)

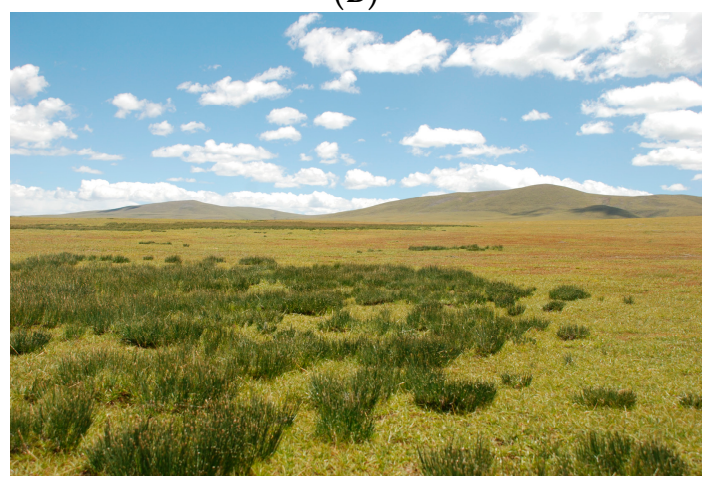

(D)

Figure 8. Artificial forests in the river valley in the Lhasa area $(\mathbf{A}, \mathbf{B})$; and alpine grassland in the Lhari County $(\mathbf{C}, \mathbf{D})$.

Besides overgrazing, land abandonment due to migration into urban areas or road construction may also attribute to the observed NDVI changes [21,32]. Our results indicate that urbanization and road construction have resulted in large area of vegetation browning (Figure 7), and the influences of road construction was more significant than urbanization with a higher browning rate within $20 \mathrm{~km}$ from the major roads. Our results suggest that urbanization and road construction have caused negative impact on vegetation greening, especially in some parts of the Lhasa area. In recent decades, warming temperature has extended vegetation growing season, causing an increase in vegetation greenness during the growing season [33]. Higher temperature in the early growing season may accelerate snow melting, making air temperature and soil moisture preferable for vegetation growth [27]. Therefore, the threat of unreasonable human activities seems to be mitigated by the potential repercussions of climate change and ecological restoration to vegetation growth.

The changes in climate variables are generally considered to be an important factor influencing vegetation growth, and warming temperature has promoted the increase of regional vegetation greening [11,18]. In this study, the increase in the annual and seasonal NDVIs all exhibited an overall increasing trend in both the Lhasa area and Lhari County during 1999-2013. Among the four seasons, the largest changing rate in the Lhasa area appeared in autumn $\left(0.0025\right.$ year $\left.^{-1}\right)$, while in the Lhari County it occurred in summer $\left(0.0029\right.$ year $\left.^{-1}\right)$. The overall patterns of seasonal NDVIs were positively correlated with rising temperatures, but negatively related with decreasing precipitations (Table 1). These results are consistent with other studies on the Tibetan Plateau [11,34] and North America [35]. However, the seasonal NDVI trends in the Lhari County were strongly regulated by the changes in climate variables than that in the Lhasa area, especially in summer NDVI, of which had a positive 
correlation with rising temperatures, and a negative relationship with decreasing precipitations in both spring and summer.

In both the Lhasa area and Lhari County, the increasing trends in the seasonal NDVIs were all noticeable for the four seasons, indicating that all seasons contributed to the increase in the annual NDVI. The greatest contribution simultaneously appeared in winter $(r=0.854,0.808 ; p<0.01)$, followed by autumn. The delayed seasonal vegetation greening in winter and autumn could be regarded as a temporal lag for vegetation growth responding to rising temperatures (Figures 4 and 5). These phenomena were not confirmed by the correlation between seasonal NDVIs and climatic factors in this study, and our results are different with the finding in the Great Plains region of North America [36]. In addition, the magnitude of the time lags may be varied spatially and temporally in different regions [37-39]. For example, the highest rate of NDVI increase in the Lhari County was in summer with a value of 0.0031 year $^{-1}$, followed by autumn $\left(0.0028\right.$ year $\left.^{-1}\right)$ and winter $\left(0.0025\right.$ year $\left.^{-1}\right)$ (Figure 5$)$, and it was generally higher than that of in the Lhasa area (varying from 0.0012 year $^{-1}$ to 0.0024 year $^{-1}$ ), except for the spring NDVI $\left(0.0008\right.$ year $\left.^{-1}\right)$. It is likely that the changes in climate variables have played a dominant role on vegetation greening in the Lhari County than that in the Lhasa area.

\section{Conclusions}

In this paper, we evaluated the nature and extent of human impact on vegetation dynamics by the comparison of NDVI changes in the relative highly populated Lhasa area and a nearby less populated Lhari County on the Tibetan Plateau. For the Lhasa area, the largest area of browning primarily distributed in the wide valleys where major road passes and cities are located in the form of fragmented patches. Human impact has mainly decreased vegetation greenness within $20 \mathrm{~km}$ of the urban area and major constructions during 1999-2013. Urbanization has resulted in vegetation browning: the closer the distance to the urban area, the lower the greening rate exhibited. The vegetation browning within $20 \mathrm{~km}$ from the major roads had greater proportion than that of around the urban area, indicating that road construction or maintenance may cause more significant vegetation browning than urbanization. For the anthropogenic factors, the annual NDVI trend in the Lhasa area was positively related to the number of rural laborers and artificial forest areas, while negatively correlated with livestock number. A similar relationship between the annual NDVI and anthropogenic factors also appeared in the Lhari County, except for artificial forest areas. The impact of anthropogenic factors on the NDVI trend is likely more apparent in the Lhasa area than in the Lhari County.

The impact of human activities in a relatively large area is still minor and does not reverse the major trends of vegetation dynamics caused by the warming temperature in recent decades. The annual NDVI values in the Lhasa area and the Lhari County both showed a significantly increasing trend during 1999-2013, with a rate of 0.0016 year $^{-1}$ and 0.0024 year $^{-1}$, respectively, at the $99 \%$ confidence level. The increase in the seasonal NDVIs were positively correlated with rising temperatures, and negatively related with decreasing precipitations in both the Lhasa area and Lhari County. The increase in the seasonal NDVIs of the Lhari County was more affected by the changes in climate variables than that in the Lhasa area. The warming temperature and the change in precipitation played dominant roles on vegetation greening in Lhari County than that in the Lhasa area. However, relatively less attention has been paid to the climatic benefits to vegetation growth produced by global warming, to better preserve the fragile environment on the Tibetan Plateau, an integrated plan should be developed to restrain the unreasonable human activities and positively adapt to the effects of global change.

Acknowledgments: This work was funded by the National Natural Science Foundation of China (Grant No. 41301611 and 41328001), and the Natural Science Foundation of Jiangsu Province, China (Grant No. BK20130103).

Author Contributions: Haidong Li, Yingkui Li, and Jixi Gao designed the research, Haidong Li and Yingkui Li conducted the analysis, and wrote the paper, Yuanyun Gao, Changxin Zou, Shouguang Yan, and Jixi Gao participated in the analysis, discussion, and paper revision.

Conflicts of Interest: The authors declare no conflict of interest. 


\section{References}

1. Sims, D.A.; Rahman, A.F.; Cordova, V.D.; El-Masri, B.Z.; Baldocchi, D.D.; Bolstad, P.V.; Flanagan, L.B.; Goldstein, A.H.; Hollinger, D.Y.; Misson, L.; et al. A new model of gross primary productivity for North American ecosystems based solely on the enhanced vegetation index and land surface temperature from MODIS. Remote Sens. Environ. 2008, 112, 1633-1646. [CrossRef]

2. Jong, R.; de Bruin, S.; de Wit, A.; Schaepman, M.E.; Dent, D.L. Analysis of monotonic greening and browning trends from global NDVI time-series. Remote Sens. Environ. 2011, 115, 692-702. [CrossRef]

3. Verbyla, D. The greening and browning of Alaska based on 1982-2003 satellite data. Glob. Ecol. Biogeogr. 2008, 17, 547-555. [CrossRef]

4. Jong, R.; Verbesselt, J.; Schaepman, M.E.; Bruin, S. Trend changes in global greening and browning: Contribution of short-term trends to longer-term change. Glob. Chang. Biol. 2012, 18, 642-655. [CrossRef]

5. Metternicht, G.; Zinck, J.A.; Blanco, P.D.; Del Valle, H.F. Remote sensing of land degradation: Experiences from Latin America and the Caribbean. J. Environ. Qual. 2010, 39, 42-61. [CrossRef] [PubMed]

6. Zhang, G.; Dong, J.; Xiao, X.; Hu, Z.; Sheldon, S. Effectiveness of ecological restoration projects in Horqin Sandy Land, China based on SPOT-VGT NDVI data. Ecol. Eng. 2012, 38, 20-29. [CrossRef]

7. Nemani, R.R.; Keeling, C.D.; Hashimoto, H.; Jolly, W.M.; Piper, S.C.; Tucker, C.J.; Myneni, R.B.; Running, S.W. Climate-driven increases in global terrestrial net primary production from 1982 to 1999. Science 2003, 300, 1560-1563. [CrossRef] [PubMed]

8. Peng, S.; Piao, S.; Ciais, P.; Myneni, R.B.; Chen, A.; Chevallier, F.; Dolman, A.J.; Janssens, I.A.; Peñuelas, J.; Zhang, G.; et al. Asymmetric effects of daytime and night-time warming on Northern Hemisphere vegetation. Nature 2013, 501, 88-92. [CrossRef] [PubMed]

9. Wu, D.; Zhao, X.; Liang, S.; Zhou, T. Time-lag effects of global vegetation responses to climate change. Glob. Chang. Biol. 2015, 21, 3520-3531. [CrossRef] [PubMed]

10. Qiu, J. China: The third pole. Nat. News 2008, 454, 393-396. [CrossRef] [PubMed]

11. Li, H.; Li, Y.; Shen, W.; Li, Y.; Lin, J.; Lu, X.; Xu, X.; Jiang, J. Elevation-dependent vegetation greening of the Yarlung Zangbo River basin in the southern Tibetan Plateau, 1999-2013. Remote Sens. 2015, 7, 16672-16687. [CrossRef]

12. Li, Y.; Liao, J.; Guo, H.; Liu, Z.; Shen, G. Patterns and Potential Drivers of Dramatic Changes in Tibetan Lakes, 1972-2010. PLoS ONE 2014, 9, 1-12. [CrossRef] [PubMed]

13. Che, M.; Chen, B.; Innes, J.L.; Wang, G.; Dou, X.; Zhou, T.; Zhang, H.; Yana, J.; Xua, G.; Zhao, H. Spatial and temporal variations in the end date of vegetation growing season throughout the Qinghai-Tibetan Plateau from 1982 to 2011. Agric. For. Meteorol. 2014, 189-190, 81-90. [CrossRef]

14. Chen, H.; Zhu, Q.; Peng, C.; Wu, N.; Wang, Y.; Fang, X.; Gao, Y.; Zhu, D.; Yang, G.; Tian, J.; et al. The impacts of climate change and human activities on biogeochemical cycles on the Qinghai-Tibetan Plateau. Glob. Chang. Biol. 2013, 19, 2940-2955. [CrossRef] [PubMed]

15. Shen, M.; Piao, S.; Cong, N.; Zhang, G.; Jassens, I.A. Precipitation impacts on vegetation spring phenology on the Tibetan Plateau. Glob. Chang. Biol. 2015, 21, 3647-3656. [CrossRef] [PubMed]

16. Rosenzweig, C.; Casassa, G.; Karoly, D.J.; Imeson, A.; Liu, C.; Menzel, A.; Rawlins, S.; Root, T.L.; Seguin, B.; Tryjanowski, P. Assessment of observed changes and responses in natural andmanaged systems. In Climate Change 2007: Impacts, Adaptation and Vulnerability. Contribution of Working Group II to the Fourth Assessment Report of the Intergovernmental Panel on Climate Change; Parry, M.L., Canziani, O.F., Palutikof, J.P., van der Linden, P.J., Hanso, C.E., Eds.; Cambridge University Press: Cambridge, UK, 2007; pp. 79-131.

17. Sparks, T.H.; Aasa, A.; Huber, K.; Wadsworth, R. Changes and patterns in biologically relevant temperatures in Europe 1941-2000. Clim. Res. 2009, 39, 191-207. [CrossRef]

18. Lü, Y.; Zhang, L.; Feng, X.; Zeng, Y.; Fu, B.; Yao, X.; Li, J.; Wu, B. Recent ecological transitions in China: Greening, browning, and influential factors. Sci. Rep. 2015. [CrossRef] [PubMed]

19. Shen, W.S.; Zhang, H.; Zou, C.X.; Cao, X.Z.; Tang, X.Y. Approaches to prediction of impact of Qinghai-Tibet Railway construction on alpine ecosystems alongside and its recovery. Chin. Sci. Bull. 2004, 49, 834-841. [CrossRef]

20. Shao, Q.; Fan, W.; Liu, J.; Huang, L.; Cao, W.; Xu, X.; Ge, J.; Wu, D.; Zhiqiang, L.; Gong, G.; et al. Assessment on the effects of the first-stage ecological conservation and restoration project in Sanjiangyuan region. Acta Geogr. Sin. 2016, 71, 3-20. (In Chinese) 
21. Qiu, J. Double threat for Tibet. Nature 2014, 512, 240-241. [CrossRef] [PubMed]

22. Guo, S.; Kang, S.; Huang, J. Seasonal variations of trace elements in precipitation at the largest city in Tibet, Lhasa. Atmos. Res. 2015, 153, 87-97. [CrossRef]

23. Li, H.; Shen, W.; Zou, C.; Jiang, J.; Fu, L.; She, G. Spatio-temporal variability of soil moisture and its effect on vegetation in a desertified aeolian riparian ecotone on the Tibetan Plateau, China. J. Hydrol. 2013, 479, 215-225. [CrossRef]

24. Nash, M.S.; Bradford, D.F.; Wickham, J.D.; Wade, T.G. Detecting change in landscape greenness over large areas: An example for New Mexico, USA. Remote Sens. Environ. 2014, 150, 152-162. [CrossRef]

25. Zhang, Y.; Gao, J.; Liu, L.; Wang, Z.; Ding, M.; Yang, X. NDVI-based vegetation changes and their responses to climate change from 1982 to 2011: A case study in the Koshi River Basin in the middle Himalayas. Glob. Planet. Chang. 2013, 108, 139-148. [CrossRef]

26. Maisongrande, P.; Duchemin, B.; Dedieu, G. VEGETATOPM/SPOT_An operational mission for the earth monitoring: Presentation of new standard products. Int. J. Remote Sens. 2004, 25, 9-14. [CrossRef]

27. Cong, N.; Piao, S.; Chen, A.; Wang, X.; Chen, S.; Han, S.; Zhou, G.; Zhang, X. Spring vegetation green-up date in China inferred from SPOT NDVI data: A multiple model analysis. Agric. For. Meteorol. 2012, 165, 104-113. [CrossRef]

28. Guo, W.; Liu, S.; Yao, X.; Xu, J.; Shangguan, D.; Wu, L.; Zhao, J.; Liu, Q.; Jiang, Z.; Wei, J.; et al. The Second Glacier Inventory Dataset of China (Version 1.0); Cold and Arid Regions Science Data Center at Lanzhou: Lanzhou, China, 2014.

29. Evans, J.; Geerken, R. Discrimination between climate and human-induced dryland degradation. J. Arid Environ. 2004, 57, 535-554. [CrossRef]

30. Wessels, K.J.; Prince, S.D.; Malherbe, J.; Small, J.; Frost, P.E.; VanZyl, D. Can human-induced land degradation be distinguished from the effects of rainfall variability? A case study in South Africa. J. Arid Environ. 2007, 68, 271-297. [CrossRef]

31. Tibet Autonomous Bureau of Statistics; Tibet General Team of Investigation under the NBS. Tibet Statistical Yearbook-2014; Chinese Statistics Press: Beijing, China, 2014. (In Chinese)

32. Runnström, M. Is Northern China Winning the Battle against Desertification? J. Hum. Environ. 2009, 29, 468-476. [CrossRef]

33. Jeong, S.J.; Ho, C.H.; Gim, H.J.; Brown, M.E. Phenology shifts at start vs. end of growing season in temperate vegetation over the Northern Hemisphere for the period 1982-2008. Glob. Chang. Biol. 2011, 17, 2385-2399. [CrossRef]

34. Shen, M.; Zhang, G.; Cong, N.; Wang, S.; Kong, W.; Piao, S. Increasing altitudinal gradient of spring vegetation phenology during the last decade on the Qinghai-Tibetan Plateau. Agric. For. Meteorol. 2014, 189-190, 71-80. [CrossRef]

35. Wang, X.; Piao, S.; Ciais, P.; Li, J.; Friedlingstein, P.; Koven, C.; Chen, A. Spring temperature change and its implication in the change of vegetation growth in North America from 1982 to 2006. Proc. Natl. Acad. Sci. USA 2011, 108, 1240-1245. [CrossRef] [PubMed]

36. Wang, J.; Rich, P.M.; Price, K.P. Temporal responses of NDVI to precipitation and temperature in the central Great Plains, USA. Int. J. Remote Sens. 2003, 11, 2345-2364. [CrossRef]

37. Piao, S.; Ciais, P.; Friedlingstein, P.; Peylin, P.; Reichstein, M.; Luyssaert, S.; Margolis, H.; Fang, J.; Barr, A.; Chen, A.; et al. Net carbon dioxide losses of northern ecosystems in response to autumn warming. Nature 2008, 451, 49-53. [CrossRef] [PubMed]

38. Richardson, A.D.; Black, T.A.; Ciais, P.; Delbart, N.; Friedl, M.A.; Gobron, N.; Hollinger, D.Y.; Kutsch, W.L.; Longdoz, B.; Luyssaert, S.; et al. Influence of spring and autumn phenological transitions on forest ecosystem productivity. Philos. Trans. R. Soc. B Biol. Sci. 2010, 365, 3227-3246. [CrossRef] [PubMed]

39. Piao, S.; Tan, T.; Nan, H.; Ciais, P.; Fang, J.; Wang, T.; Vuichard, N.; Zhu, B. Impacts of climate and $\mathrm{CO}_{2}$ changes on the vegetation growth and carbon balance of Qinghai-Tibetan grasslands over the past five decades. Glob. Planet. Chang. 2012, 98-99, 73-80. [CrossRef]

(C) 2016 by the authors; licensee MDPI, Basel, Switzerland. This article is an open access article distributed under the terms and conditions of the Creative Commons Attribution (CC-BY) license (http://creativecommons.org/licenses/by/4.0/). 